\title{
Yellow vs. Red and the Rise of a New Middle Class in Thailand
}

\author{
Apichat Satitniramai ${ }^{1}$
}

During the last two decades, Thailand's political climate had changed profoundly, resulting in an unprecedented divide between two fronts: the socalled Yellow Shirts (People's Alliance for Democracy, or PAD) and the Red Shirts (United Front for Democracy against Dictatorship, or UDD). Both parties are currently locked in an arduous conflict, with the Yellows initiating a mass mobilization to oppose the Reds who represent the anti-coup forces who have rallied around exiled Prime Minister Thaksin Shinawatra and his alleged 'nominee' governments.

This divide is perhaps the first example of nationwide mass politics in Thai political history. It is no surprise, then, that this phenomenon has provoked both Thai and foreign academics alike to seek explanations for the emergence of these political mass movements. In this chapter I posit that this issue is not so much about clashes between the 'haves' and the 'have-nots', or elite conflicts carried over to the clientelist masses of supporters. I argue, instead, that we are looking at the coming-of-age of a new Thai middle class. This idea is supported by recent research on the socio-economic characteristics of both the Reds and the Yellows.

The Yellows are representative of the 'old' established middle and upper classes, who have been well integrated economically and politically with the elites since the 1970s. The Reds, on the other hand, are identified as the vanguard of an emerging class of lower middle-income, market-oriented earners, the product of Thailand's economic growth during the past two decades. It is this emerging class, and not the poor, that forms the majority of voters in Thailand's electoral system at present. The livelihoods of the members of this class depend crucially on market transactions, both in consumption and production, while the persistence of considerable economic inequality, together with the development of electoral politics at the national and local levels, has

1 I would like to thank the TUHPP for funding this project and thank all eight members of the research team for their comments during discussions and exchanges of ideas, as well as for their suggestions for data from which this article has benefited. Any errors this chapter might contain remain the responsibility of the author alone. 
propelled them to emerge with a sense of citizenship. Critically, they have come to realize that electoral politics is the form of institution that serves their interests best.

In contrast, the 'old' middle and upper classes presently comprise the minority of voters. Although more powerful economically, their political significance is threatened by the growing significance of electoral politics. The electoral victories of the Thai Rak Thai party and its successor parties caused their political influence to diminish, thereby provoking much resentment. And from November 2013 to May 2014, a political group - an alliance between factions of the Yellows and the Democrat Party, calling itself People's Democratic Reform Committee $^{2}$ - occupied central Bangkok. The months-long occupation created a pretext for the coup on 22 May 2014 that brought Thailand under military control. The conflict between the Reds and the Yellows, therefore, might be seen as a clash between the growing political aspirations of and emerging class and resentment among the middle and upper classes over the resulting changes.

As the introductory chapter of this book suggests, a study of citizenship in Southeast Asia might need to develop an analysis of citizenship that is sensitive to class differences as well as possible rural - urban divides' since 'heterogeneous populations claim diverse rights and benefits associated with citizenship. I propose in this chapter that the current political conflict between the Yellow and the Red Shirts may be understood as a class conflict. Not in the traditional meaning of a class struggle between a working class without the means of production and an oppressive capitalist class, or between the rich and the poor - which has been suggested by Ungpakorn (2009), Hewison (2012), Taylor (2012) and Forsyth (2010), but as a conflict between the newly emerging lower middle class (the Red Shirts) and the old middle class (midmiddle class and higher) that comprise the Yellow Shirts.

This article is divided into six sections. The first section tests proposals drawn from empirical data on the identities of the Red Shirts and Yellows Shirts, and discusses their socio-economic characteristics. In the next part, the formation of these two mass movements as social classes is contextualized historically through a discussion of the changing socio-economic conditions in Thailand during the last two decades. The third and fourth sections discuss the respective interests of the two sides, and addresses the question whether their political conflicts can perhaps be seen as a class conflict. The fifth part discusses whether these mass mobilizations and conflicts imply or

2 The Democrat Party is the oldest political party in Thailand but became the main 'permanent' opposition party since the establishment of the Thai Rak Thai government in 2001. 
reflect changing meanings of citizenship, while the final section comprises the conclusion of the study.

\section{Who are the Red and the Yellow Shirts?}

It could be claimed that the literature concerning the current colour-coded conflict in Thailand can be divided into two strands. The first is predominately represented by left-leaning scholars, such as Ungpakorn (2009), Hewison (2012), Taylor (2012) and Forsyth (2010). These authors analyse the conflict mainly as a working-class-based movement against the exploiting class, or a 'class war' (Ungpakorn 2009:76). They describe the supporters of the Red Shirt movement as 'rural and working-class people', and 'people who [experience] disadvantage[s] and exploitation' (Hewison 2012:157), 'the lower and middleincome peasantries of Thailand' (Forsyth 2010:465), 'urban and rural poor' (Ungpakorn 2009:76), or a 'marginalized subaltern peasantry' (Taylor 2012:296). On the other hand, they identify the Yellow Shirt supporters as 'the middle classes and rich elites' (Ungpakorn 2009:76, 82), or 'the minority elites and Bangkok middle class' (Taylor 2012).

In contrast, the liberal-minded authors of literature on the Red versus Yellow conflict, such as Naruemon Thabchumpon and McCargo (2011), Keyes (2010), Walker (2012) and Pattana Kittiarsa (2012), argue that the Red Shirt movement is mainly supported by economically better-off rural-born Thais, and not the poor. For example, Naruemon Thabchumpon and McCargo (2011) characterize the Red Shirts as 'urbanized villagers', while Keyes (2010) and Walker (2012) identify them as 'cosmopolitan villagers' and 'middle-income peasants' respectively.

Although this second group of academics acknowledge that the Red Shirt supporters have a lower socio-economic status than their yellow-clad fellow countrymen, they do not consider this colour-coded conflict as a class war. The Red movement, after all, does not intend to overthrow the state but aims to assert the political rights of its supporters and to obtain state subsidies within the framework of a parliamentary democracy. Although both analyses present a general image of the current Thai political divide, their characterization of the conflict lacks large-scale quantitative evidence.

The first quantitative study which attempted to adequately describe the demographic and socio-economic characteristics of the Reds and Yellows was conducted by Ammar Siamwalla and Somchai Jitsuchon (2012). The study surveyed a nationwide 4,097 households in August and September 2009 and, surprisingly, found that factors such as economic status (rich or poor), region 
(northeast, north, et cetera), and employment status (employer, employee or self-employed) did not indicate the likelihood of being a Red Shirt. Therefore, it seems that the general belief among the Thais that the poor always support the Red Shirt movement is a myth. Their second conclusion reads that 'there is a clear tendency for better-off people to be Yellow'. Thus 'Bangkok people, across all income classes, are more likely to be Yellow, while outside Bangkok the better-off are more likely to be Yellow' (Ammar and Somchai 2012:66).

A survey with a sample size of 2,200 in five provinces, from the project Reexamining the Political Landscape of Thailand (Apichat et al., 2013) and conducted by Wanwiphand in April-June 2012, further confirmed Ammar's and Somchai's (2012) conclusions. Wanwiphand found that, firstly, Red Shirts were more likely to have lower socio-economic status than Yellow Shirts, and were also more likely to work in the agricultural or informal sectors. In contrast, it was found that more Yellow Shirts than Red Shirts were civil servants, state employees, or businesspeople. Secondly, more Yellow Shirts than Red Shirts had completed a higher level of formal education. As for incomes, the income levels of both Yellow and Red Shirts were not statistically different. Thus Yellow Shirts have higher economic and social status than Red Shirts, with a higher level of education and more secure employment in business or as professionals. A Red Shirt generally has a lower level of education, and earns an irregular income as a commercial agriculturalist or (semi-)skilled labourer, or is selfemployed in the informal sector. It should be noted here that the Red Shirts are not always necessarily among the poorest; it turns out that they generally have higher incomes than Thais who are 'apolitical.' 3

Although these two recent studies disagree on a number of issues (such as the employment status of the Yellow and Red Shirts), they both consider the Red Shirts as having a lower socio-economic status than the Yellow Shirts. Based on these findings, I postulate that the majority of the Red Shirts comprise an emerging lower middle class whose members are found in both urban and rural areas. This view opposes the categorization found in the above mentioned literature that describes the Red Shirts as mainly rural poor, workingclass people, or non-poor rural residents. As for the Yellow Shirts, I follow Nithi Eawsriwong $(2008,2010 a)$, who concurs that the Yellow Shirt supporters are members of the established middle class, especially in urban areas. ${ }^{4}$

3 According to our survey, the 'apolitical' group is the smallest group. It composed $5.42 \%$ of the total samples, while the Red Shirts, the Yellow Shirts and the 'Neutrals' composed $46.75 \%$, $28.44 \%$ and $19.39 \%$ of the samples.

4 See Nithi Eawsriwong 'The reformulation of the political system' and 'Who Are the Yellow Shirts and Why Have They Emerged?' 


\section{A New Middle Class: Socio-economic Changes during the Last Two Decades}

The above line of reasoning suggests that the struggle of the Red versus Yellow Shirts can be partly attributed to the political rise of this new, lower middle class. The Thai Rak Thai (TRT) party noticed this group, and designed policies to transform this new social force into the base for their party. The question is how this new middle class gained political prominence? The answer to this question lies in the socio-economic changes during the last two decades.

As of the late 1980s, Thailand has seen a continuous sharp growth of its economy and, as a result, has been 'upgraded' by the World Bank from a lower middle-income to an upper middle-income country. From 1986 to 2009, Thailand's Gross Domestic Product grew considerably and the average income increased to six thousand baht in 2009 (TDRI 2011:47-48). During this period, the average household income increased by as much as $8.8 \%$, while household expenditures grew by $7 \cdot 3 \%$. Household savings and assets accumulated as well. Not surprisingly, the percentage of people living under the poverty line declined dramatically from $42.2 \%$ in 1988 to $7.7 \%$ in 2010, that is just over five million people. Moreover, the incidence of poverty in rural areas decreased from $49.7 \%$ to about $10 \%$, whereas in urban areas it fell from $23.7 \%$ to $2.6 \%$ in the same period (Pasuk and Pornthep 2012:13-14).

In parallel with the increase in average income and the decrease of poverty, the structure of production in Thailand shifted from the agricultural sector to the industrial and service sectors. This change was reflected in shifts in the occupational structure. The number of agricultural households tended to decline by $1 \%$ per year, while unskilled labour decreased as well. Simultaneously, the proportion of three other occupational categories - business owner, professional/technician, and clerical-sales-services - started to grow. The number of people employed in industrial production and crafts rose sharply between 1986 and 2006, but fell slightly between 2006 and 2009 (TDRI 2011:37).

In 2009, 5 those with more than five thousand baht income per capita per month were identified as middle class. This means that, of the above occupational categories, only farmers and those earning an income with unskilled labour have not reached middle-class status $(32 \%$ of total households in 2009, reduced from $55 \%$ in 1986). Among the middle class as a whole, people working in clerical-sales-services and industrial production are categorized as lower middle class. They make up $35 \%$ of total households, and have an average income per month of 5,000-10,000 baht. In this lower middle-class group, the sales-and-services group grew sharply from $10 \%$ of all households

5 In 2009, the poverty line was 1,586 baht per capita per month. 
in 1986 to $20 \%$ in 2009. This section expanded from urban to rural areas and from Bangkok to other regions, and has an average income of 5,828 baht per month. This is similar to the income of industrial production workers, and almost twice as high as that of farmers. However, this level of income is still lower than the average income per capita (6,239 baht) in 2009 (TDRI 2011:38). In conclusion, the lower middle class, excluding farmers, comprises around one-third of households in Thailand.

The extensive changes in the agricultural sector of the last twenty years resulted in the formation of a new, lower middle class. Reviewing the past of the Thai agricultural sector and looking into its future, Ammar Siamwalla (2004:11) concluded that the Thai rural areas will gradually achieve a better status. The general belief, particularly prevalent among the middle class of Bangkok, that rural equals agriculture equals poverty, is likely to become less true. Between 1989 and 1998, more than 3,5 million male and female workers and students, aged 15-34, left agriculture and rural areas for the cities. After having left, these young people did not return to their rural home region to work in agriculture. This caused a severe labour shortage in the agricultural sector. Farmers coped with this shortage by turning to machinery and other, technological, means. Combined, these drastic changes made that farming ceased to be a family activity.

Currently, Thai rural society no longer functions as a traditional peasant society, as it has split into two groups: professional/commercial farmers and traditional/subsistence farmers. Farmers from the first group tend to be younger, make more use of modern production techniques and are more capable of dealing with market fluctuations. Also, their farms are usually larger, as they use machinery and hired labour to overcome family labour shortages. A professional farmer generally earns far more than the average traditional farmer. Professional/commercial farmers will become the largest group of the agricultural sector in the future.

The Food and Agricultural Organisation of the United Nations (FAO 2006: II, 40-41) defines professional farmers as households that obtain more than $60 \%$ of their total income from agriculture and where the head of the household has no secondary job. Its findings show that there were 1.36 million professional farmer households (that is $19 \%$ of farm households) in 2004 compared to 0.94 million in 1986 . While the number of farm households increased by $23 \%$ in that period, so did that of professional farm households, by $45 \%$ that is. The latter's monthly income increased from 2,525 to 9,311 baht, whereas that of traditional farmers during the same period increased only from 941 to 1,366 baht. Moreover, a professional farmer's income is almost $75 \%$ above the average income of a traditional farmers. We can therefore identify this group 
of farmers as a new middle class in the agricultural sector. ${ }^{6}$ The traditional farmers are elderly people, whose children have left home and who rely on their childrens' remittances from outside the agricultural sector. They practice subsistence agriculture and will become increasingly less important for the agricultural sector in the future.

The shift of the agricultural sector away from a traditional farming society is also visible in the diversity of new occupations that sprung up in the rural areas, such as construction work, contracting, hairdressing, beauty therapy, retail sales, selling prepared food and motorcycle and agricultural machinery repair. In the past, these occupations did not exist in these areas due to insufficient demand. Therefore, the proportion of farmers has shrunk not only as a part of the total population, but also as a part of the rural population.

Keyes (2010) portrays the changes that have taken place in the Thai countryside over the past fifty years in his fieldwork in Nong Tuen village, Mueang District, Mahasarakham Province. His findings largely substantiate the view of Ammar Siamwalla. Keyes found that, in 2005 , not a single family in this village was growing rice for sale; they grew it for consumption by their extended families. For example, in a family with two sons and two daughters in this village, both sons and one son-in-law drove taxis in Bangkok. The second daughter lived in the village and grew rice to sustain all four families, using a capitalintensive method of farming in all stages of production (Keyes 2010:15-16). The three family members in Bangkok regularly sent money home and occasionally travelled home to provide labour. From this perspective, it is no surprise that these three taxi drivers called themselves 'villagers' or 'farmers', even though nearly all of their income came from the non-agricultural sector. Keyes further shows that migration from the agricultural sector to the cities first only involved men, but that later, women also began leaving their village for the city. This first-hand experience with living and working outside the village, as well as the arrival of education and the penetration of mass media during the last two decades, have all greatly transformed the worldview of these 'villagers', to the point where, these days, the label 'cosmopolitan villagers' seems more fitting for them.

From the above discussion of Ammar Siamwalla and Keyes, we may infer that Thai rural society is no longer a static traditional farmer or peasant society. Although Thai living in rural regions and villagers mainly living in the

6 From the figure of $19 \%$, we can roughly estimate that this forms $5 \%$ of the total number of households in the country since agricultural households make up at least $25 \%$ of all households. Thus in 2009, the lower middle class households - both within and outside agriculture - constituted $40 \%$ of Thai households. 
cities still consider themselves as 'villagers' and 'farmers', their economic way of life is fully market-oriented, whether they worked in the agricultural sector or not. These 'farmers' enjoy higher incomes than they did in the past, but their main source lies outside the agricultural sector. Summarizing these findings, it can be said that Thai socio-economics have changed greatly, and that these changes entailed the formation of a new middle class, whose members are found both within and outside the agricultural sector and rural regions. At the same time, the poor have become a societal minority. Now that it has been explained how it mainly is the Red Shirts who enjoy this new, middleclass socio-economic status, it is time to address their common interests and concerns.

Despite an overall improvement in the standard of living in Thailand, the income disparity between the poor and the rich remains large. Inequality over the past two decades, as measured by the Gini coefficient using household income, has improved only slightly, while the coefficient measured by household income has worsened. In contrast to many ASEAN neighbours which

Gini

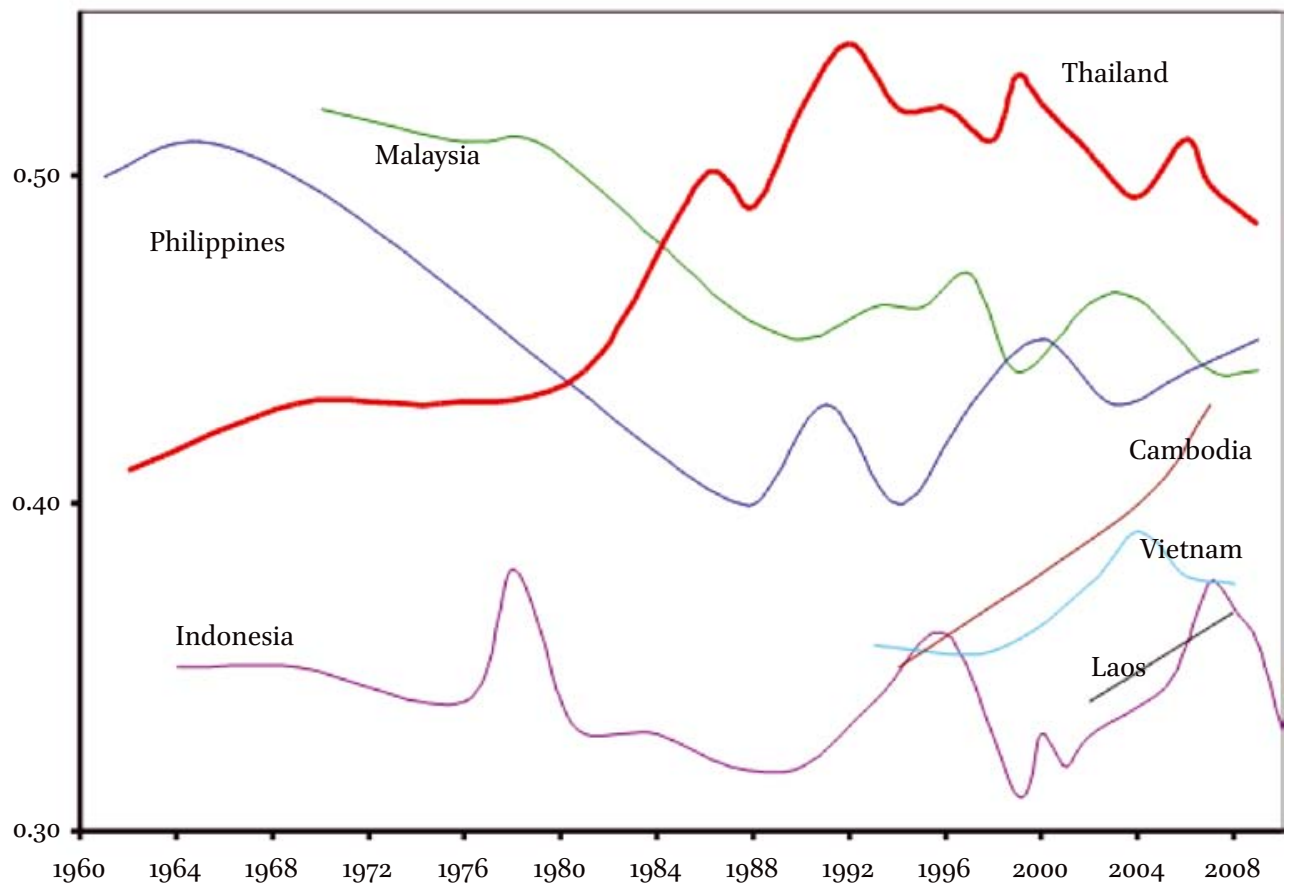

FIGURE 12.1 Gini coefficients of household income, selected Southeast Asian Countries SOURCE: PASUK AND PORNTHEP (2013:11). 
have declining income inequalities, Thailand's Gini coefficient has tended to increase over the past fifty years of economic development.

Household income inequality in Thailand, measured by the share of total consumption expenditure, is expressed in Figure 12.2. The share of the top $20 \%$ of the population with the highest expenditure slowly declined from $50.05 \%$ in 1996 to $46.68 \%$ in 2010 . In contrast, the share of expenditure of the bottom $20 \%$ with the lowest consumption increased slightly from $6.10 \%$ in 1996 to $6.76 \%$ in 2010 (Pasuk and Pornthep 2012:15-6). This economic inequality is even more pronounced when we consider the asset inequality: the top $20 \%$ has sixty-nine times more assets than the bottom 20\% (Pasuk and Baker 2012:219).

Turning to wage inequality, the poorest $10 \%$ of workers earned just $1.85 \%$ of the total wage income in 2006 , with an average wage income of 1,468 baht $(38.7$ us dollar) per person per month. This share increased slightly in 2010 to $2.22 \%$ with an average income at 2,133 baht (67.2 Us dollar). The top earners' share of total wages also increased from $35.11 \%$ to $36.96 \%$ between 2006 and 2011 . The ratio between the wage share of the highest and the lowest declined from 18.97 in 2006 to 16.66 in 2010 (Pasuk and Pornthep 2012:16-17). Meanwhile, the share of wages in the factor incomes, which is a rough measurement of income distribution between capital and non-capital owners, hovers at around 0.5-0.6, making Thailand's wage share relatively low when compared with developed economies (0.65-0.7 in EU and US). Moreover, between 2002 and 2009, the real Gross Domestic Product grew at around $5 \%$ per year, while real wages of workers only grew at the yearly rate of $1.4 \%$. And labour productivity rose at an average annual rate of $3.6 \%$ between the fourth quarter of 2002 and the first

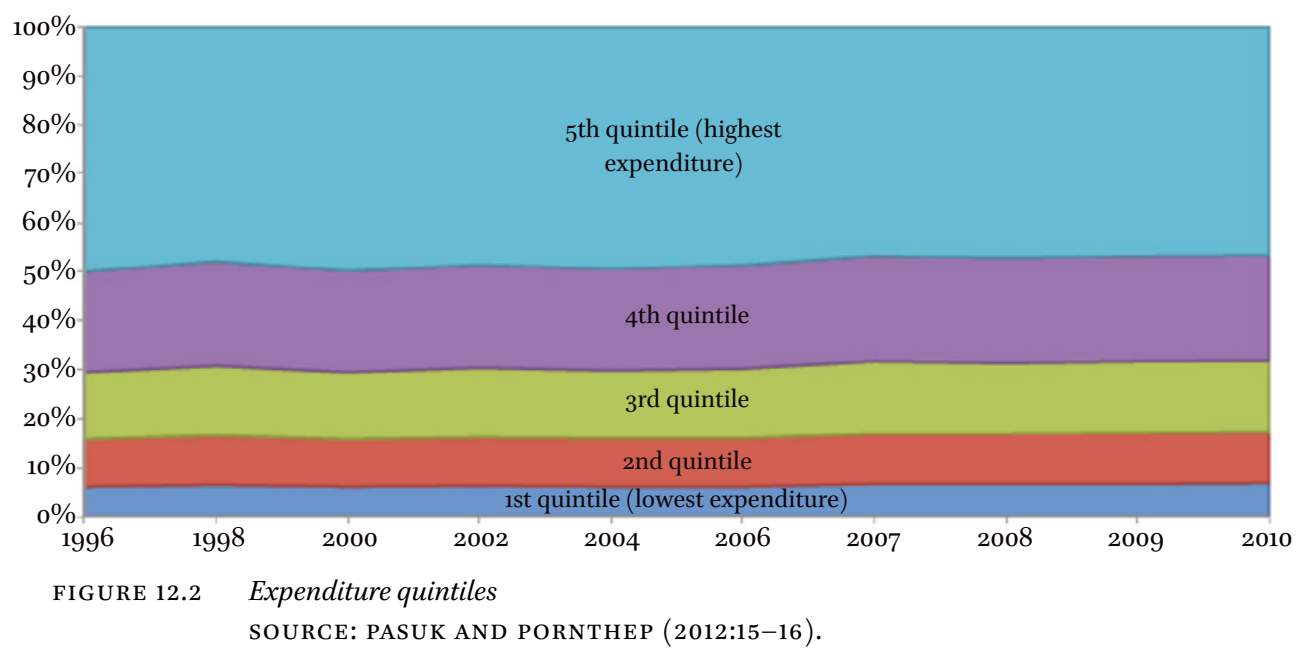


quarter of 2008. This means that the gains from productivity growth have not been accruing to labour wages, but to the employer instead (Pasuk and Pornthep 2012:19, 21).

Apart from healthcare, ${ }^{7}$ coverage of employment benefits and other social welfare benefits, such as old-age pensions, has been limited. In 2014, only $25.1 \%$ of the total labour force were covered by the social security system, which also provides maternity benefits, child allowances, unemployment benefits and an old-age pension scheme. Another $12.7 \%$ are public employees and state enterprise workers who have different pension schemes. Approximately two-thirds of the labour force (about 24 million workers or $62-64 \%$ of the population in the period 2005-2010) were not covered by any old-age pension scheme as they worked in the informal sector (Pasuk and Pornthep 2012:18).

The above discussion makes clear that the 'lower middle class' or the 'new middle class' is a product of socio-economic changes in Thailand, especially during the past twenty years. This class is present in both urban and rural areas and its members are found both inside and outside the agricultural sector. Based on the data presented in footnote six above, it is estimated that in 2009, this new middle class constituted around $40 \%$ of the total households in Thailand. Although members of this group are not among Thailand's poorest, they are less well-off than the average middle class and upper class members in terms of both income and assets. Also, many who belong to this new middle class lack social security as they work in the non-formal sector.

The way of life of this group in both production and consumption is closely tied to the Thai capitalist system; many are petty traders and self-employed workers, such as taxi drivers, motorcycle taxi riders, motorcycle mechanics and hairdressers. And, if they are farmers, they are market-oriented professional/ commercial farmers, not traditional/subsistence farmers.

Similar to the old middle class, these people expect to do well and raise their social and economic status under the modern market system. The main difference is that their general capabilities - such as level of education, skills and/or access to capital and economic and social opportunities - are lower than those of the old middle class, thus creating a 'new' middle class with lower economic status than its predecessors. Because their employment is often outside the formal sector, they have no social security protection and, as their employment is closely tied to the market system, their income is uncertain and vulnerable

7 At present, the universal healthcare programme covers $75.2 \%$ of the population. Before the programme started in 2001, this population had no state-provided health insurance. 
to economic fluctuations. At the same time, they are faced with an immense inequality of income, assets and life-opportunities, as the education and other public services they have access to are of inferior quality. In order to rectify these inequalities, the members of this new middle class need social security and support from the state to help them raise their economic status to something close to that of the old middle class.

When the first Thaksin government pushed forward and implemented their campaign promises in the 2001 election, Prime Minister Thaksin Shinawatra and the Thai Rak Thai party became very popular and were greatly admired by the new middle class. This support continued to the present day. The main reasons for this general appreciation were their social programme policies such as universal healthcare, debt rehabilitation and village funds - as these responded to and coincided with the economic demands of the new middle class. These policies, labelled degradingly as 'populist' by some, were intended to improve the lives of the new middle class in various ways. The health insurance programme provided extra security, while other programmes focused on increasing economic opportunities, such as the 'village fund' for cheap loans, or a programme called 'OTOP' which opened up new opportunities for incomegenerating activities.

Thaksin's first government was the first elected government in Thai political history that used these national-level policies to attract enough votes to win an election and then successfully implemented them. Red Shirts who admire Prime Minister Thaksin are likely to say that his policies are concrete, tangible and 'edible' since they make a concrete difference in their daily lives. The universal healthcare scheme, for example, has for some decided on matters of life and death. As it was the lower middle class that directly benefitted from these new policies, they led to an increase in the popularity of Prime Minister Thaksin and the Thai Rak Thai government among members of this class, and increased support for the Red Shirt movement.

I claim that the emergence of this new middle class formed the basis for the formation of the Red Shirt movement. This does not mean, however, that all members or even the majority of this new class are Red Shirts. Neither does it say that members of other economic classes - rich or poor - cannot join the Red Shirts, or, for that matter, that members of the new middle class cannot become a Yellow Shirt, or remain neutral. An individual may or may not choose a political identity, and that person's economic status is not necessarily a deciding factor in specifying their identity. However, given the above survey data, I do argue that a significant number of Red Shirts are people from this new middle class. 


\section{From Subjects to Citizenship: Political Changes and New Citizenship}

The emergence of the new middle class described above is the material basis that facilitated the creation of a new social force of actors in Thai political society. This chapter suggests that political changes over the last ten years have created a new form of political consciousness in members of this group that led to the birth of the Red Shirts. They no longer perceive themselves as commoners, servants or subjects without rights or a voice in the running of their country. Instead, they see themselves as citizens or partners in Thai political society, with an inherent right to co-design their country's fate.

The problems these people were facing in their daily lives were fundamentally political problems, not economic hardship or lack of state support in itself (Nithi 2010b). ${ }^{8}$ What they needed was to develop a political space to further their own interests. As a Red Shirt furniture maker in Chiang Mai Province stated: '[in the past] I relied little on state policy. I planted crops in rotation, melons after rice. I did not think about state policy. I thought that I had to help myself. I had land before, but not enough to sustain me and my family. We have to depend more on state policy and I felt elections were more important for me. 9

Cherishing the right to vote is an inseparable part of the concept of citizenship among the Red Shirts. They define elections as the minimum requirement for a country to be considered a democracy; every individual equally has one vote to appoint or remove their government. ${ }^{10}$ One Red Shirt, defining democracy, said: 'It must come directly from the people. As long as we have to wait for permission [from the authorities], it is not democracy. There must be the right to choose our leaders. If they are no good, we will decide. Our people must not be ousted by a coup.11 Thus, a coup by the ruling class as an instrument for annulling elections or interfering with election results is, according to the Red

$8 \quad$ Nithi Eawsriwong 'Political Space that Cannot be Closed Off'.

9 Interview with a group in a village in Doi Saket District, Chiang Mai Province, January 2011.

10 Certainly, there is a great diversity of political ideologies among the Red Shirts, but I wish to define the main common denominator in the thinking of the Red Shirts. That is that they believe that elections, in the sense that every person has an equal right to appoint and remove the administration, are a necessary condition of a democracy. Although opinions may vary on whether the right to vote is the only condition of a democratic system, a democracy without elections or with elections that are controlled, in one way or another, by the elite, is not deemed a democracy.

11 Interview with a group in Thonburi, Bangkok, 2010. 
Shirts, a form of politics that lacks legitimacy, as it denies them their share of politics and closes down their political space. Voting is their basic mechanism for pushing and negotiating their interests. The question is how this particular concept of citizenship came about? I believe that we have to look at past political developments for the roots of Thai citizen consciousness.

The foundations of electoral politics at the national level were set in the 1980 s under a semi-democratic system. Although it was an electoral system controlled by the ruling elite, national level elections of Members of Parliament took place regularly, and this led people to believe that the normal role of citizens in politics was to elect the politicians that form the government. So a coup d'état, or other overt political intervention, was considered un-democratic.

In elections before 2001, voters did not directly benefit from policies at the national level, since the content of those national policies was dominated by high ranking bureaucrats and technocrats. Elected politicians had a minimal role. Concrete national policies hardly played a role in electoral campaigns, while the idea of implementing these policies after the election was even less important. The reason for this is that before 2001, national policies favoured local projects, mostly development projects, for which MPs could acquire central budgets, to the benefit of their own constituencies. Or private funds were distributed in cash to individuals during election campaigns.

Thus the 2001 election was the first time ever that a Thai political party - the Thai Rak Thai - operated more or less like a 'programme-based' party, contrasting with an old-style 'clientelistic' parties. ${ }^{12}$ It is no surprise, therefore, that when coups did interrupt the electoral cycle before 2001, such as in 1991, mass opposition movements did not arise as there were no national benefits from the elections to protect.

The key turning point was when the 1997 Constitution came into force. This constitution regulated two issues in particular that turned out successful in their implementation. First, it aimed to facilitate the creation of a strong executive branch to make the Thai state work more effectively. Second, the constitution mandated an unprecedented level of decentralization that transferred a certain degree of power and authority to local governments. Furthermore, Constitution encouraged the formation of big political parties and party policy platforms by changing from multiple-seat constituencies to single-seat constituencies and introducing a party list system, and increased the bargaining

12 See the distinction between clientelistic and programmatic political parties in Kitschelt (2000). 
power of the prime minister and party leader over the cabinet and leaders of political factions.

For instance, the election law required MP candidates to be party members for at least ninety days, and regulated that elections are to be held no longer than sixty days after the House of Parliament is dissolved. Other rules were designed to facilitate a more practical and stable governance by incentivizing politicians to build bigger parties. This would turn, it was believed, the previously fragmented party system into a consolidated two-party system (Hicken 2006). In other words, the 1997 Constitution was designed to give the government more power to devise, reform and implement policies in order to effectively tackle the problems it is faced with.

The Thai Rak Thai party, under the leadership of Thaksin, won the first election under this constitution in 2001, and fully benefited from these new rules. The result was that, for the first time in Thai political history, a government won an election by campaigning on the basis of proposals for national-level policies, and successfully implemented these policies shortly after the election. The popularity of Prime Minister Thaksin and the Thai Rak Thai party increased dramatically. And, more importantly, they won a landslide victory in the following election that enabled them to successfully form a single-party government for the first time in Thai history. The success of the Thaksin government, in which the 1997 constitution played an important role, made voters realize that their votes were 'edible' in the form of national policies.

The constitution also brought about decentralization, forcing the central government to transfer power and budgets to local administrative organizations (LAOS) to an unprecedented degree. At present, it cannot yet be said that the level of decentralization allows LAOs enough freedom for local people to be able to govern themselves independently from the central state - as was the idea behind the decentralization, since control by the central government is still relatively high. However, since 2003, the 7,775 municipal and sub-district administrative organizations and seventy-five Provincial Administrative Organizations (PAOs) throughout the country have, for the first time, had their administrative and legislative bodies elected directly from the local people.

Even though the mechanism of direct elections alone will not ensure complete accountability of LAOs to the people, a survey by the King Prajadhipok Institute (2010) found that there was an increase in the confidence of the people in the work of LAOs from $63.5 \% 2002$ to $71.8 \%$ in 2005. A comparison between the level of confidence in the work of the central government and cabinet, and that in local administrative organizations, shows that the confidence increased from 2007 onward. Satisfaction with the services of local administrative organizations rose from more than $80 \%$ in 2005 to $89.7 \%$ in 2010. 
From this perspective, it can be stated that the large-scale decentralization resulting in the formation of LAOs through direct elections have made local elections more important and meaningful in the daily lives of people in each locality. There are several reasons for this.

Firstly, the duties and resources of LAOs have greatly expanded since 1999. The total current revenue of LAOs nationwide is about $25 \%$ of the central government revenue, and the duties and responsibilities of LAOs have had a direct and clear effect on the livelihoods of voters. Secondly, it is relatively easier for people to make the candidates account to them, especially at the sub-district and municipal level. This is because these localities tend to be small, and the physical and social relationship between candidates and voters is more intimate. It should, therefore, come as no surprise that elections at this level have become much more competitive.

Furthermore, interviews show that villagers in rural areas base their choice for candidate LAO members on the candidate's potential capability to attract development projects and other resources from the central government for the benefit of their own community (Apichat et al., 2010). This is because approximately $40 \%$ of LAO budgets still directly derive from central government subsidies. Moreover, the criteria for allocating budget subsidies of many different kinds to LAOs in each locality empower the central power holders to use broad discretion. This forces LAOs to lobby the central government to obtain higher allocations (Apichat 2011:29-35). This shows that villagers use local elections as a tool to bargain for resources from central government.

In summary, both national and local elections are of more significance to the lives of voters than ever, especially since the proclamation of the 1997 constitution. Political awareness, especially in valuing the right to vote, has increased greatly over the past decade or so.

Against this background, the reactions to the 2006 coup d'état formed a tectonic shift. This coup was different from the previous ones as it was the first coup that yielded a nation-wide mass counter-movement. Resistance to the earlier coups in October 1976 and February 1991 had been limited and concentrated in the old middle class in the urban areas. The new middle class had not yet emerged, and the majority of the population did not yet conceive of themselves as citizens. The 2006 coup brought about a political awareness that the overthrow of the elected Thaksin government was the expropriation of the citizens' right to vote, the latter being the new middle class' most effective political bargaining tool.

The coup lighted the fuse on a political bombshell and paved the way for the formation of the Red Shirt political movement. The Red Shirt movement is an alliance of very loose, mass-based organizations and groups of politicians of 
the former Thai Rak Thai party, led by Thaksin Shinawatra. All one needs to do to identify oneself as a Red Shirt is to join political activities organized by local or national- level Red Shirt groups.

Attempts by some Red Shirt groups to establish a formal membership structure failed, but the movement has been strengthened and consolidated in other ways. In particular, the Reds gained momentum around 2010, after the dissolution of the People Power Party (the reincarnation of the Thai Rak Thai party - which had been disbanded earlier by the judiciary). These developments had been set off by the Yellow Shirts' counter-movement against the elected Samak Sundaravej government and Somchai Wongsawat government in 2008. The massive rally staged by the Red Shirts in Bangkok to call for the dissolution of parliament in 2010, forms yet another illustration of how the Red Shirts movement aims to protect the electoral rights of the new middle class.

\section{What is the Old Middle Class Fighting for?}

Thirty percent of the Thai households derive their income - ranging from almost 15,000 to 20,000 baht in 2009 - from professionals, business owners and industrial workers (TDRI 2011:37-38). This is the middle class, I argue, that provides mass support for the Yellow Shirt mass movement. One can even say that the Yellow Shirts movement forms the frontline of this 'old' middle class. Members of this old middle class are well-off and enjoy high levels of economic security. Thus they have fewer economic demands to negotiate with the state in comparison with the new middle class. The former was the first group to grow up during the economic development of the 1960 s and benefitted directly from the economic growth. From this time on, they have had access to major services provided by the state, including better quality higher education, medical services and social security as well as other forms of infrastructure such as roads, water and electricity, et cetera. Crucially, this class does not have to rely on elections as it has many effective forums and mechanisms at its disposal for negotiating their interests with the Thai state. For example, all branches of the mainstream media are the representatives and mouthpieces of this class, to the point where no past government has been able to survive without taking criticism from the mass media into account.

Another reason why the old middle class, numerically smaller than the new middle class, has bargaining power with the state is its importance in the country's economic structure. Elections are important in bargaining with the state, but for the old middle class, they are not the main political tool. Due to this class' minority status in the country and their urban residence, the establishment of electoral politics at both the national and local levels, especially from 2001 
onward, greatly diminished this group's political influence on the government. Conservative political parties which have long been popular with this class, like the Democrat Party, have not won recent national elections. As the electoral system of the 1997 constitution turned Thai politics into a competition between two big parties, the old middle class' representatives became a single, 'permanent' opposition block. This situation differs significantly from the pre2001 era, when Thai governments were always coalitions, frequently involving the Democrat Party. Over the past ten years, national electoral politics has reduced the political influence of the old middle class.

Similarly, the expansion of local electoral politics, especially after 2003, brought very little benefit to the old middle class. This is because members of this class generally live municipal areas or large cities like Bangkok, where its residents had been granted the right to elect their local government already before 2003. The new middle class - found mostly in rural areas - on the other hand, could elect their administrators only in 2003, under the Tambon Administrative Organizations regulation.

The expansion and establishment of elections at both the national and local levels has not provided extra benefits for the established middle class, while it reduced their political influence. It is therefore no surprise that the ideological strategy of the Yellow Shirts, apart from monarchism, is to diminish, deemphasize and even destroy electoral politics. The slogan '4-second-democracy', used by the Yellow Shirts, describes the 'immorality' of the electoral system as the core problem of the Thai political system. This is because, the Yellows claim, capitalist politicians can become parliamentary dictators and monopolize political power by buying MPs and votes of rural people who are considered as being undereducated, ignorant and poor. ${ }^{13}$ Instead, they propagate a 'New Politics', with $70 \%$ of MPs being appointed and $30 \%$ elected. This would yield, they believe, a new kind of politician, with ethics and morality, to govern the country.

Summarizing, the Yellow Shirt mass movement attempts to preserve their political influence by limiting the impact of electoral politics. They mock electoral politics by comparing it to a soap opera: meaningless, amoral, and not stimulating to the mind. According to the Yellow Shirts, electoral politics is the vehicle of dirty politicians and their henchmen.

13 See, for example, a Yellow Shirt protester from southern Thailand who took part in the protest against the Yingluck's Government in December 2013, who said that, 'We know what is right and wrong, ...but the poor don't know anything. They elect the people who give them money' http://www.nytimes.com/2013/12/04/world/asia/thailand-protests -reflect-searing-divisions-of-changing-country.html?pagewanted=2\&_r=1 last accessed on 16 January 2014. 


\section{Citizenship and the State: From Clients to the New Thai Citizens}

The introductory chapter of this book discusses how 'patronage democracies' 'are succeeding in winning elections by using...their "money power" to buy voters'. And while 'efforts to woo voters by presenting some sort of policy platform is kept to a minimum...the activities of political parties are mostly geared towards facilitating clientelistic exchanges between politicians and voters, rather than facilitating public debate or developing programmatic policy agendas'. The analysis in this chapter suggests that the socio-economic and political development of Thailand over the last two decades has reduced the effectiveness of clientelism as a method of electoral mobilization.

Firstly, as noted above, the main result of the 1997 Constitution was state strengthening and the facilitation of a more effective government by way of programmatic political parties. The constitution encouraged the formation of party policy platforms by introducing a party list electoral system which designates the whole country as a single constituency with a proportional voting rule. This system incentivized political parties to design a national level policy platform in order to maximize votes and, at the same time, discouraged specific, particular, regional or locally focused policies or 'club goods'. Since the first general election held under these new rules in 2001, political parties have responded enthusiastically, with their policy manifestos becoming increasingly important for winning an election.

It can even be claimed that the new electoral system is extremely successful in generating national level policy platforms, especially in terms of redistributing the state's resources to the new middle class at the expense of the old middle class. This is because the new middle class comprises the majority of the voters, while the old middle class represents a minority. And, as expected, this redistribution leads to political conflicts between the two classes. Since Thaksin's party policy platform did promise material improvements to the voters and since the state's resources were redistributed to the voters after the election, one might argue that Thaksin and his party mobilized votes through clientelism.

However, this argument misses the point. Focusing on clientelism as a method of electoral mobilization, Stokes $(2009)^{14}$ points out that it is the distributive criterion of electoral support that distinguishes clientelism from other materially oriented political strategies, namely the programmatic redistributive politics. She defines clientelism as 'the proffering of material goods

14 Strokes, S.C. (2009) 'Political Clientelism' The Oxford Handbook of Comparative Politics http://www.oxfordhandbooks.com/search?siteToSearch=aup\&q=Political+Clientelism+ \&searchBtn=Search\&isQuickSearch=true. Last accessed on 3 March 2014. 
in return for electoral support, where the criterion of distribution that the patron uses is simply: did you (will you) support me?,'15 while the criterion for benefitting from redistributive programmes is: do you occupy a given class of beneficiaries (such as the unemployed, or the retired)? Programmatic benefits, therefore, redistribute resources from classes of non-beneficiaries to classes of beneficiaries. But within a class of beneficiaries, particular people who qualify cannot be excluded.

By contrast, clientelist redistribution always involves exchange. The benefit is only available on the condition that the client complies with the request to provide political support. As pointed out above, the social policies of Thaksin's government, especially universal healthcare, debt rehabilitation and village funds, are the main sources of his popular support. All of those policies' criterions for beneficiaries are non-discriminating, and therefore it cannot be argued that the rise of Thaksin was completely due to a narrow interpretation of clientelism as a method of electoral mobilization.

Consequentially, the practice of vote-buying, although still widespread, is no longer the decisive factor in winning general elections. As argued by Pasuk Phongpaichit (2013), a respected political economist, the pattern of election results has changed. In the past, vote-buying became manifest in election results of adjacent constituencies, showing different parties as winners by highly varying margins. However, in the last decade, this pattern has disappeared. Presently, because mass sentiment is driving the result, constituency after constituency across whole regions are choosing the same party, and by huge margins. This new pattern first appeared in the south in the 1980s, especially after Chuan - the former prime minister - became the Democrat Party leader. The southerners decided that the party was 'their' party, and voting Democrat became part of their regional identity.

Since then, the same pattern has emerged in the northeast and upper north. At the 2011 poll, in constituency after constituency in the northeast and upper north, Pheu Thai - the successor of the Thai Rak Thai party - won 50-60\% of the vote, while the second-place candidate won only $10-20 \%$. If vote-buying is determining the election results, then the question remains: why would the parties buy far more votes than they need to win? Moreover, the survey of the project Re-examining the Political Landscape of Thailand (Apichat et al., 2013) also found that $60-70 \%$ of the correspondents stated that the money they received from politicians had no effect on their decision to choose candidates, both at the national and local election.

15 Emphasis in the original. 
To sum up, political changes, especially the 1997 constitution, have incentivized politicians to change their parties from clientelistic parties into programmatic ones; only by adopting this strategy would they have a chance to win. As a result, voters were able to choose between competing party policy platforms of parties. While a large number of voters still accepted vote-buying money, policies turned out the decisive factor in their electoral choice. We might therefore conclude that it is no longer appropriate to consider the combination of vote-buying and clientelism as a method of electoral mobilization, as the winning strategy of electoral politics in Thailand.

\section{Conclusion}

In this chapter, I have proposed to understand the current political conflict between the Red and Yellow Shirts as a class conflict: not in the traditional meaning of a class struggle between the working class without the means of production and an oppressive capitalist class, or between the rich and the poor, but as a conflict between the newly emerging lower middle class (the Red Shirts) and the old middle class (mid-middle class and higher), known as the Yellow Shirts.

The Red Shirts are the representatives of a new middle class which emerges in both urban and rural spaces, both within and outside the agricultural sector, and in both the formal and informal sector. These people became the new lower middle class as their income rose above the poverty line. This chapter has shown how the conception of Red Shirts as non-poor rural Thais - 'urbanized villagers' (Naruemon Thabchumpon and McCargo 2011) or the 'middle income peasants' (Walker 2012) - does not hold, as a significant number of Red Shirt supporters can be found in non-farm sectors and urban areas. Currently, this new class forms the majority of the population in Thailand.

Even though economic growth in the past two decades has lifted these people out of poverty, inequality of income and assets between this new and the old middle class has remains consistently high. Red Shirts continue to lack social and economic security. Political developments, especially the establishment of electoral politics over the past ten or more years, have created their political consciousness and notion of citizenship. This means that they began to see themselves as stakeholders in society with the right to participate in crafting their own future. However, despite being the majority in Thai society, they still have limited political space and bargaining tools. Elections is their only effective political tool to negotiate state policies that benefit the new middle class citizens. In this sense the emergence of the Red Shirt movement is not 
directly related to economic inequality. The disparity of wealth and income between classes in Thailand has been consistently high since the late 1970s (see Figure 12.1 above). The Red Shirts' emphasis on a 'right to have rights' was mainly a response to political changes, such as the enactment of the 1997 Constitution which made their right to vote meaningful for the first time ever. In this regard, the disparity of wealth may be viewed as a secondary factor that reminds the Red Shirts of the injustices they have suffered, and are still suffering to a certain degree, and that propels them to exercise their rights in order to rectify them.

The 2006 coup d'état and the political developments that followed temporarily negated their citizenship and destroyed their only political tool. It made the Red Shirts realize that they have a 'right to have rights', especially the right to vote and to be counted as equal a citizen as the Yellow Shirts. From this perspective, the aim of the political struggle of the Red Shirts is to guard electoral politics, which is the political institution that protect their interests best.

In contrast, the establishment and expansion of electoral politics at both the national and local levels has reduced the political influence of the old middle class. Elections have never been important or meaningful in the daily lives of this group. Not only are they, in quantitative terms, a minority in Thai society, they also have other political mechanisms and spaces that, in their hands, are more effective than elections for negotiating with, and pressuring governments to promote the policies they benefit from. The mass media is one of these 'spaces' that the Yellow Shirts deploy to further their cause. As a faithful mouthpiece of the old middle class, the media propagates a Thai politics that protects the political influence of the old middle class at the cost of democratic electoral politics.

The political conflict between the Red and Yellow Shirts is about distributive politics. The Reds are staunch protectors of the democratic elections since it is their weapon to pressure the government to allocate resources for their benefit, while the Yellows are threatened by these same elections as they reduce their political role and influence. In these terms, this chapter argues against the perception that this clash is an elite conflict, with both movements as mere political pawns of the elite (as suggested by Crispin 2012). It proposes, instead, to understand the conflict as a class struggle.

The political divide is stemming from the fact that the Yellow Shirts are attempting to deny the Red Shirts political equality as citizens. Socio-economic and political changes have lifted them out of poverty and their old clientelistic exchanges with politicians, and they now realize that they have a 'right to have rights'. And they are ready to fight for that right. Thus, it can be said that the Red Shirts have become 'new Thai citizens'. In this light, I agree with the 
conclusion by Wolfram Schaffar (Chapter 10 in this volume) that 'any concept of citizenship in postcolonial countries that operates with the dichotomy of a rights-conscious, urban middle class versus clientelistic rural poor runs into difficulties with regard to the dynamics of citizenship in Thailand'. I propose to use the term 'new Thai citizen' for the Red Shirt supporters in order to emphasize that they are 'newcomers' who are fighting for effective rights to participate meaningfully in the polity, especially via their voting rights. The Red Shirts are not fighting for the legal recognition of their right to vote as universal suffrage has been granted since the revolution in $193^{2}$ - but for their right to participate in a meaningful way in the democratic politics of their nation.

\section{References}

Ammar Siamwalla (2004). 'The Old Age of the Agricultural Sector: the Past and Future of Thai Rural Areas.' Paper presented at the 2004 TDRI Year-end conference, Pattaya, 27-28 November, 2004 (in Thai).

Ammar Siamwalla and Somchai Jitsuchon (2012). The Socio-Economic Bases of the Red/Yellow Divide: A Statistical Analysis. In M.J. Montesano, Pavin Chachavalpongpun, \& Aekapal Chongvilaivan (Eds.), Bangkok May 2010: Perspectives on a Divided Thailand (pp. 64-71). Singapore: ISEAS Publishing.

Apichat Satitniramai (2011). 'Constitution, Decentralization and Popular Participation.' Paper presented at the Annual Conference of the Faculty of Economics, Thammasat University, Bangkok, 20 July 2011 (in Thai).

Apichat Satitniramai, Yukthi Mukdawijit, Niti Pawakapan, Wanwipang Manachotipong, Praphat Pintoptang, and Naruemol Thapchumpol (2010). Preliminary Report of the Project on Socio-Economic Changes of the New Emerging Class.' Research report for the Thai Health Promotion Foundation, funded by the Thai Universities for Healthy Public Policy (TUHPP), Public Policy Studies Institute (PPSI), Chiang Mai University (in Thai).

Apichat Satitniramai, Yukthi Mukdawijit, Niti Pawakapan, Wanwipang Manachotipong, Praphat Pintoptang, Viengrat Netipho, Jakrit Sangkamanee, Pinkeaw Leang-aramsri, and Anusorn Unnol (2013). 'Re-examining the Political Landscape of Thailand.' Research report for the Thai Health Promotion Foundation, funded by the Thai Universities for Healthy Public Policy (TUHPP), Public Policy Studies Institute (PPSI), Chiang Mai University (in Thai).

Crispin, S.W. (2012). Thailand's Classless Conflict. In M.J. Montesano, Pavin Chachavalpongpun, \& Aekapal Chongvilaivan (Eds.), Bangkok May 2010: Perspectives on a Divided Thailand (pp. 108-119). Singapore: ISEAS Publishing. 
Food and Agricultural Organisation of the United Nation (FAO) (2006). Rapid Growth of Selected Asian Economies: Lessons and Implication for Agricultural and Food Security, Republic of Korea, Thailand and Vietnam. Policy Assistance Series 1/3, Bangkok: FAO Regional Office for Asia and the Pacific.

Forsyth, T. (2010). Thailand's Red Shirt Protests: Popular Movement or Dangerous Street Theatre? Social Movement Studies:Journal of Social, Cultural and Political Protest, 9 (4), 461-467.

Hewison, K. (2012). Class, Inequality, and Politics. In M.J. Montesano, Pavin Chachavalpongpun, \& Aekapal Chongvilaivan (Eds.), Bangkok May 2010: Perspectives on a Divided Thailand (pp. 141-160). Singapore: ISEAS Publishing.

Hicken, A.D. (2006). Party Fabrication: Constitutional Reform and the Rise of Thai Rak Thai. Journal of East Asian Studies, 6 (3), 381-407.

Keyes, C. (2010). From Peasant to Cosmopolitan Villagers: Refiguring the 'Rural' in Northern Thailand. Special lecture organized by the Anthropology Graduate Program, Bangkok: Thammasat University, on 15th November 2010.

Kitschelt, H. (2000). Linkages between Citizens and Politicians in Democratic Polities. Comparative Political Studies, 33 (6/7), 845-879.

Naruemon Thabchumpon and McCargo (2011). Urbanized Villagers in the 2010 Thai Redshirt Protests: Not Just Poor Farmers? Asian Survey, 51 (6), 993-1018.

Nithi Eawsriwong (2008). 'The reformulation of the political system.' Matichon Raiwan, 25 August 2008, 31, 111125 (in Thai).

Nithi Eawsriwong (2010a). 'Who are the Yellow Shirts and why have they emerged?' Matichon Online, 12 July 2010 [cited 26 May 2012]. Available from http://www .matichon.co.th/news_detail.php?newsid=1278919534\&grpid\&catid=02 (in Thai).

Nithi Eawsriwong (2010b). 'Political Space that Cannot be Closed Off.' Matichon Online, 29 November 2010 [cited 26 May 2012]. Available from http://www .matichon.co.th/news_detail.php?newsid=129101680o\&grpid\&catid=02\&subcatid= 0202 (in Thai).

Pasuk Phongpaichit and Baker, C. (2012). Thailand in Trouble: Revolt of the Downtrodden or Conflict among Elites? In M.J. Montesano, Pavin Chachavalpongpun, \& Aekapal Chongvilaivan (Eds.), Bangkok May 2010: Perspectives on a Divided Thailand (pp. 214-229). Singapore: ISEAS Publishing.

Pasuk Phongpaichit and Pornthep Benyaapikul (2012). Economy of Tomorrow: A Technical Note on Thailand. Paper presented at the FES (Friedrich Ebert Stiftung) Regional Forum on the Economy of Tomorrow, 1-2 March 2010, Pullman Hotel, Bangkok: organized by FES and TDRI.

Pasuk Phongpaichit and Pornthep Benyaapikul (2013). Political Economy Dimension of a Middle Income Trap: Challenges and Opportunities for Policy Reform Thailand. In Adam Burke (Eds.), Middle Income Trap: Economic Myth, Political Reality: Case Studies from Malaysia and Thailand, Bangkok: The Asia Foundation. 
Pasuk Phongpaichit (2013). Vote-buying claims nothing but dangerous nonsense. BangkokPost, 6 Dec 2013, Retrieved from http://www.bangkokpost.com/opinion/opinion/ $383418 /$ vote-buying-claims-nothing-but-dangerous-nonsense, last accessed on Jan 16th 2014 .

Pattana Kittiarsa (2012). From Red to Red: An Auto-ethnography of Economic and political Transitions in a Notheastern Thai Village. In M.J. Montesano, Pavin Chachavalpongpun, \& Aekapal Chongvilaivan (Eds.), Bangkok May 201o: Perspectives on a Divided Thailand (pp. 230-247). Singapore: ISEAS Publishing.

Strokes, S.C. (2009). Political Clientelism. The Oxford Handbook of Comparative Politics Retrieved from http://www.oxfordhandbooks.com/search?siteToSearch=aup\&q=P olitical+Clientelism+\&searchBtn=Search\&isQuickSearch=true, last access on 3 rd March 2014.

Taylor, J. (2012). No Way forward but Back? Re-emergent Thai Falangism, Democracy, and the New "Red Shirt" Social Movement. In M.J. Montesano, Pavin Chachavalpongpun, \& Aekapal Chongvilaivan (Eds.), Bangkok May Strokes, 20og: Perspectives on a Divided Thailand (pp. 286-312). Singapore: ISEAS Publishing.

Thai Development Research Institute (TDRI) (2011). 'Report on the Life of Thais in Two Decades of Development: the Significance of Public Policy Changes on the Livelihoods of Thai Households'. Research report for the Thai Health Promotion Foundation, funded by the Thai Universities for Healthy Public Policy (TUHPP), Public Policy Studies Institute (PPSI), Chiang Mai University, September 2011 (in Thai).

Ungpakorn, G., (2009). Class struggle between the coloured T-shirts in Thailand. Journal of Asia Pacific Studies, 1(1), 76-100.

Walker, A. (2012). Thailand's Political Peasants: Power in the Modern Rural Economy. Madison: The University of Wisconsin Press. 